\title{
Effects of Change Management On Skills Retention in A Division of a Multinational Company
}

\author{
Sagashen Pillay ${ }^{1}$, Prof Muhammad Hoque, PhD $^{2}$ \\ ${ }^{1}$ Graduate School of Business \& Leadership, College of Law and Management Studies, University of \\ KwaZulu-Natal \\ ${ }^{2}$ Senior Research Associate, Management College of Southern Africa
}

\begin{abstract}
In the transformation process, the issue of key skills retention became fairly pertinent to the success of such change. The need to understand the business change process and the human factor are key drivers. Therefore, the objective of this study was to determine the effects of change management occurring within a multinational company. This cross-sectional quantitative study was conducted among all the employees of this company using a selfadministered anonymous questionnaire. The results revealed that the majority of the participants indicated that their career paths were not mapped out, the recent restructure of the company positively affected their conditions of employment, and there was no adequate consultation prior to the transition process. About two-thirds of the participants $(63 \%)$ mentioned that they are currently seeking new employment opportunities because their jobs were not secure and they were anxious and worried about the future. The majority of the participants believed that management initiatives implemented would not sustain the business in the long term. There are opportunities in securing the skills required for future business changes as well as encouraging responses indicated by current staff who are willing to improve the shortfalls for business stability.
\end{abstract}

Keywords: Career-mapping; commitment, communication and cooperation; motivational theories 


\section{INTRODUCTION}

Effective leadership, learning and change are converging in the global world to form business cultures that when they converge are capable of producing enormous economic value to their customers, employees, stakeholders and communities (Terblanche, 2014). The resultant challenge facing companies is the ability to formulate an effective program to retain skills that may be considered critical in achieving or maintaining organisational goals.

With the increase in globalisation, especially in the automotive components industry from leading countries like China and India, the need to foster trade ties has been the focus for companies in countries that want to remain in business into the next decade (Bloom \& Van Reenen 2010:215). Globalisation has increased the level of competitiveness in industries and through improved information technology the ability to tap into new markets through the web. Overall, international trade has created a world in which the bar that marks 'good enough' keeps moving progressively higher (Begbie, Bussin \& Schurink, 2011:323).

Dhliwayo (2014:122) further adds that competitiveness is the single major obstacle facing business today. Through securing a competitive advantage in the market place, stimulation to the customer to buy from a specific business rather than the competitor is fostered. Organisations are often forced to implement new strategies in the shortest possible timeframe due to industry challenges. However, there is little or no consideration as to how skills are to be effectively retained (Bloom \& Van Reenen 2010:233). This places a greater focus on workforce capabilities and has fundamentally transformed the psychological nature of employment contracts. The idea of 'a job for life' - one career path in one organisation has changed and has resulted in career expectations that include periods in more than one organisation and more than one career in a working life.

Businesses like Company $\mathrm{X}$ now have to face transformation to new business strategy models, which involves new products, services, new customers, new competencies and capabilities in the view of Van Dyke and Coetzee (2012:4) who maintains that when people have been rewarded for doing something over and over, they take great pride and comfort in doing it. Ochurub, Bussin, and Goosen (2012:13) add that change requires learning and the development of new skills, forming new relationships and disrupting one's personal life. To remain competitive, the shifting of business platforms has become the norm to be sustainable into the future (Ochurub et al., 2012:13).

\section{LITERATURE REVIEW}

Worldwide companies are seeking better and improved methods regarding their approach in business, driven by the impact of globalisation and growing competition. The need for increasing predictability by getting processes under control is, therefore, fundamental (Du Toit \& Sewdass, 2014:14). Williams (2013:21) maintains that even though most people accept that change is inevitable, they are generally ill-equipped for the process and firefighting that becomes the norm. With employment being deeply entwined within the process of change there is a need to focus on how this change perpetuates the loss of skills and what is required to be done in redressing the situation (Nujjoo \& Meyer 2012:10).

\subsection{Retention factors}

Retention can be defined as the process that drives the inherent needs of employees to remain or depart from an organisation, depending on their priorities (Theron, Barkhuizen \& Du Plessis 2014:7). Furthermore, Faught (2012:17) defines retention as the assimilation of 
activities that cohesively result in employees staying at organisations for lengthy periods. Research has focused on the various aspects that explain the reason for employees leaving organisations. However, the issue that remains is that when the employees move they not only take skills and knowledge but also trade secrets to the competitor organisations (Weisul, 2011:11).

Compensation: Van Dyke and Coetzee (201211) point out that the issue of financial compensation is a key precursor of intentions to leave. Coetzee, Mitonga and Swart (2014:19) challenge that the employment relationship is predominantly driven by management and is seen as a one-way process. Coetzee et al., (2014:19) add that once an individual has accepted a contract of employment, the issue of fairness in compensation is also driven by management processes leaving the employee to review whether it is fairly done or not. Van Dyke and Coetzee (2012:14) support the view and maintain that transparency and consistency are vital in ensuring that the issue of compensation becomes a criterion for retention rather than the loss of key employees.

Job characteristics: The emphasis here is that specialisation can sometimes alienate employees to a point where their skills become redundant to the needs of the business so training needs should be carefully analysed and relevant to the job function. Employees in general seek a need to deliver excellent results and want to take on tougher challenges that are applicable to the organisation (Mosavi \& Gaedhi 2012:19).

Training and development: Job rotation as stressed by Joāo (2010:63) is another option as it allows individuals to understand their strengths and weakness and stimulates the training process. Shumba and Naong (2012:41) adds that training and regular feedback enables employees to envisage achievement through success in work situations where there is personal involvement.

Management support: Using mechanisms such as training feedback protocols once back at the workplace are vital in ensuring that the training provided is effectively transferred and secondly provides a platform for recognition. Van Dyke and Coetzee (2012:28) re-iterate that mentoring is another tool that can become a source of effective succession planning as it re-enforces management-perceived commitments.

Career development: This aspect includes the internal and external career growth charting that employees may be given. The term 'development' is considered as the process of gaining new skills and taking advantage of many different methods of learning that benefit both the employees and the organisation alike (Van Rooyen, Du Toit, Botha \& Rothman, 2010:87). Internal career opportunities could exist with the business and the opportunity to cross-train becomes another vital tool. Outside the business opportunities, this could mean transferring to another business unit according to (Joāo 2010:62).

Work-life balance: This is especially relevant in our technologically advanced environment today. It includes the support of employees through the use of IT support at home, childcare facilities in the working environment, as well as employee assistance programs that ensure the work-life balance policy positively influences the employees' attachment to their organisations (Coetzee et al., 2014:32).

Gender parity: Von der Ohe and Martins (2010:44) raise the issue of the 'glass ceiling' which is the invisible barrier blocking women and minorities from management or skilled positions in organisations. With employment equity plans being reviewed annually by the Department of Labour, companies in South Africa are now forced to ensure that there is compliance. 


\subsection{Understanding change}

Ochurub et al., (2012:41), supported by Burger, Crous and Roodt (2013: 76) discussed the issue of Kotters' (1988) syndrome of mismanagement and reflected on the ability of managers to respond to pressure specifically during a change process. These organisations find that they do not possess managers who are skilful in handling change due to their fear of failure. The argument is that strong organisations can retain the elements that create and nurture failure unless managers learn to be successful and adaptable. There follows a period of easy success and growing organisational complexity, followed by declining performance resulting in poor management performance and inward-driven focus. The final result is 'fear of failure' and a lack of credibility amongst top management (Ochurub et al., 2012:42). Von der Ohe and Martins (2010:68) views that the change process is more likely to fail if it is inconsistent with any of the three levels of organisational culture. They maintain that management needs to have access to a complete database of change strategies to handle current challenges.

A change process is easy to implement. However, understanding the direction is a start to the process (Von der Ohe \& Martins 2010:72). The 'process' being discussed is a form of influence in which the management of the enterprise attempts to get employees to behave, think or perform differently. The possible outcomes of influence, in general, are compliance, commitment or resistance. Resistance is, therefore, viewed as a failure influence attempt and must be defined so that it is overcome and minimised.

As human beings are creatures of comfort they do not have enthusiasm for change at the workplace (Von der Ohe \& Martins, 2010:73). Managers have to learn how to overcome this behaviour to reduce the costs associated, namely decreased employee loyalty and difficulty in addressing a failed attempt to change. Khoele and Daya, (2014:37), on the other hand, believe that there is an extensive platform of planned change literature together with change management models available. However, the key characteristics of these models often reflect (N number of steps) and functionally adhering to sequential straight-line patterns. Schreuder and Coetzee (2010:45) support that the generic change model is partly focused on empirical studies. In practice, it essentially means that the organisational behaviour generally follows a routine of 'planned change'.

\subsection{The engagement of staff}

Managing staff turnover during turbulent times poses a challenge to most organisations and the key is to capitalise on skills developed within the organisation thereby ensuring staff are understood and managed (Terera \& Ngirande, 2014:482). Kaliannan and Adjovu (2015:73) define engaged employees as those who are psychologically fully committed to their work roles. The varying levels of engagement have been described by Meyer, Roodt and Robbins (2011:112) through three distinct platforms, namely:-

Engaged: This is an employee with a profound connection to their company who is passionate about driving the business forward.

Not engaged: This refers to an employee who attends work but is only there to earn a salary with no passion for their work.

Disengaged: These are employees who are unhappy in their work and this is shown through their non-delivery of performance.

While the link to employee morale and job performance has been obscure in the past, the Gallup $\mathrm{Q}^{12}$ Employee Engagement Survey demonstrates that the stronger the work relationship the better the occupational outcomes. The four distinct stages begin with the 
need to understand expectations, and then be provided with the right tools thus enabling performance and finally career growth (Faught, 2012:32).

\subsection{Talent management}

Uys, Schutte and Esterhuizen (2011:62) maintain that in determining a business strategy, it is essential to take into consideration the existing talent within a company. Once the fiveyear business plan has been defined by the board of directors with its human resource department, together with line managers, (normally within each discipline like engineering, customer centre, production, and logistics), identification of the competencies required to achieve the company's required talent need (Uys et al., 2011: p 64) takes place. On the aspect of soft skills, the use of development tools like $360^{\circ}$ assessment and one-on-one performance appraisals can further assist. These tools provide a substantial basis for training needs which further help in understanding one's career path (Ochurub et al., 2012:69).

\subsection{The integrated use of the Human Resource Department}

The primary function of a company's HR department is to ensure their human resources division is utilised and managed as effectively as possible. The management of personnel has seen a minimum of three distinct approaches since the turn of the last century, in scientific management, human relations and the HR approach (Von der Ohe \& Martins, 2010:87). The challenges facing practitioners include improving the quality of working life, redesigning jobs around this concept, and hiring and motivating the diverse workforce while enabling the company to successfully compete.

\subsection{The HR challenge into the 21st century}

The biggest challenges, as depicted in Figure 2.10, that companies face today is the drift from traditional personnel approaches that were conceived in cultures driven by control and command, to approaches characterised by greater employee commitment, cooperation and communication (Swanepoel, Botha \& Mangonyane, 2014:525). Developing the capacity for flexibility in a competitive business environment is considered a vital component for the achievement of a company's change in business strategy. The impact of a well-versed human resource department in supporting the change in business strategy cannot be overestimated (Swanepoel et al., 2014:114).

\section{METHODOLOGY}

This study has been based on empirical research employing a quantitative approach. The reason for selecting the quantitative approach is to answer the main research problem, which enabled deductive reasoning to be used. Govender and Mbhele (2014:67) maintain that this process best aligns with the relationship between theory and practice.

The simple random sampling method was selected to identify a sample from a target population in which all the elements in that sample had an equal chance of being selected which generalised in respect of the entire population (Sekaran \& Bougie, 2009). The sample size to be applied was, therefore, 97 persons.

A structured anonymous questionnaire had been chosen as the research instrument which had been based on the quantitative research approach.

The questionnaires were completed in person with each participant, as initial attempts in email proved fruitless with poor responses, beyond the reality that most employees worked on the shop floor. A covering letter was attached outlining the purpose of the study with an emphasis on confidentiality aspects. This letter also explained that the information would be used for research 
purposes only. At the outset, the respondents were advised that participation was voluntary and would remain anonymous if requested so.

All respondents, from management to shop floor personnel, greatly appreciated face-to-face contact rather than through email or a third party as it was a practical option in light of the layout expanse of the manufacturing plant.

Once captured, the raw data was converted using the SPSS (Statistical Package for the Social Sciences) dataset which according to Sekaran and Bougie (2009) can analyse statistical data and provide descriptive statistics such as plots and frequencies.

\section{RESULTS}

One hundred participants completed the questionnaire from a total of 108. The participants' socio-demographic details are summarised in Table 4.1. It was found that the majority of the participants $(72 \%)$ were male. With regards to marital status, more than half of them (56\%) were married followed by single (28\%) and the balance either divorced or widowed. Results showed that fewer than a third (36\%) were working in the production department and $23 \%$ were from the engineering department. Less than a third of the participants had an undergraduate degree or higher (31\%), and about a third had a non-technical qualification $(32 \%)$. The majority of the participants $(83 \%)$ had more than 10 years of working experience.

Table 4.1: Socio-demographic information of the participants

\begin{tabular}{|l|c|c|}
\hline Variables & Frequency & Percent \\
\hline Sex & & 72.0 \\
\hline Male & 28 & 28.0 \\
\hline Female & & \\
\hline Marital status & 3 & 3.0 \\
\hline Widow/Widow & 13 & 13.0 \\
\hline Divorced/Separate & 28 & 28.0 \\
\hline Single & 56 & 56.0 \\
\hline Married & & \\
\hline Department & 11 & 11.0 \\
\hline Others & 8 & 8.0 \\
\hline Logistics & 16 & 16.0 \\
\hline Maintenance & 6 & 6.0 \\
\hline Customer Care & 36 & 36.0 \\
\hline Production & 23 & 23.0 \\
\hline Engineering & & \\
\hline Education qualification & 6 & 6.0 \\
\hline Others & 15 & 15.0 \\
\hline Did not complete matric & 30 & 30.0 \\
\hline Completed Matric & 18 & 18.0 \\
\hline Diploma & 15 & 15.0 \\
\hline Undergraduate & 16 & 16.0 \\
\hline Post Graduate & & \\
\hline Technical Qualification & 20 & 20.0 \\
\hline Incomplete Training toward Trade qualification & 7 & 7.0 \\
\hline Trade Tested Artisan Fitting\& turning & & \\
\hline
\end{tabular}




\begin{tabular}{|l|c|c|}
\hline Variables & Frequency & Percent \\
\hline Trade Tested Artisan Tool making & 9 & 9.0 \\
\hline Trade Tested Artisan Millwright & 11 & 11.0 \\
\hline Trade Tested Artisan Electrician & 6 & 6.0 \\
\hline Plastics Federation (Level 1-6) & 9 & 9.0 \\
\hline Artisan Electronics & 6 & 6.0 \\
\hline Others & 32 & 32.0 \\
\hline Work Experience & & \\
\hline 1-5 years & 4 & 4.0 \\
\hline 6-10 years & 17 & 17.0 \\
\hline 11-15 years & 35 & 35.0 \\
\hline 16-20 years & 23 & 23.0 \\
\hline 20+ years & 21 & 21.0 \\
\hline
\end{tabular}

Results showed that more participants indicated that their career path was not mapped out and monitored (74\%), 70\% did not know that there was a mentorship program in place, and $71 \%$ mentioned that they did not understand the company grading system. It was also found that almost all the participants $(91 \%)$ agreed that the company should undergo annual performance reviews and that the process be transparent (Table 4.2).

Table 4.2: Frequency distribution of statements regarding skilling

\begin{tabular}{|c|c|c|c|}
\hline Statement & Unsure & No & Yes \\
\hline Do you believe that the company's training is relevant? & 18.0 & 60.0 & 22.0 \\
\hline $\begin{array}{l}\text { Is there a process of cross-training on-site supported by } \\
\text { you and your manager? }\end{array}$ & 2.0 & 35.0 & 63.0 \\
\hline $\begin{array}{l}\text { For your career path do you understand the company } \\
\text { grading system? }\end{array}$ & 3.0 & 71.0 & 26.0 \\
\hline $\begin{array}{l}\text { Is there a defined process for career planning and skills } \\
\text { development to encourage you to remain on-site? }\end{array}$ & 11.0 & 58.0 & 31.0 \\
\hline $\begin{array}{l}\text { Do you annually undergo a performance review and is } \\
\text { the process transparent? }\end{array}$ & & 9.0 & 91.0 \\
\hline Is your career path mapped out and monitored? & 7.0 & 74.0 & 19.0 \\
\hline $\begin{array}{l}\text { Do you know if there is a mentorship program in place } \\
\text { and if it is supported? }\end{array}$ & 10.0 & 70.0 & 20.0 \\
\hline
\end{tabular}

The majority of the participants $(75 \%)$ mentioned that the recent restructure positively affected their conditions of employment. More than two-thirds of the participants (70\%) indicated that there was no adequate consultation prior to the transition process. It was found that $70 \%$ of the participants disagreed that employees were provided with adequate information on the change process. The results showed that $72 \%$ of the participants reported that management had not been supportive during the transition phase. 
When participants were asked about the critical or highly-valued skills required on this business site, the first choice was Millwright (60\%), followed by Toolmaker and Fitting and Turning $(34 \%, 30 \%)$ respectively (Table 4.3$)$.

Table 4.3: The critical or highly-valued skills required on this business site

\begin{tabular}{|c|c|c|c|}
\hline Rank of Choice & Section & Frequency & Percent \\
\hline First choice & Millwright & 60 & 60.0 \\
\hline Second choice & Toolmaker & 34 & 34.0 \\
\hline Third Choice & Fitting \&Turning & 30 & 30.0 \\
\hline Fourth Choice & Electrician & 61 & 61.0 \\
\hline Fifth Choice & Tech Furnace & 54 & 54.0 \\
\hline Sixth Choice & Machine setter & 93 & 93.0 \\
\hline Seventh Choice & Machine operator & 94 & 94.0 \\
\hline
\end{tabular}

About two-thirds of the participants $(63 \%)$ mentioned that they are currently seeking new employment opportunities because their jobs are not secure (Table 4.4).

Table 4.4: Statements that best describe your job intentions

\begin{tabular}{|l|c|c|}
\hline \multicolumn{1}{|c|}{ Statement } & Frequency & Percent \\
\hline $\begin{array}{l}\text { I am currently seeking new employment opportunities } \\
\text { because I fear that my job is not secure. }\end{array}$ & 63 & 63.0 \\
\hline $\begin{array}{l}\text { Even though I would like to quit working for this } \\
\text { business, I believe that the options externally are } \\
\text { limited. }\end{array}$ & 7 & 7.0 \\
\hline $\begin{array}{l}\text { I am committed to working for this company as I } \\
\text { believe that it provides me with the best opportunity to } \\
\text { meet my obligations. }\end{array}$ & 30 & 30.0 \\
\hline
\end{tabular}

When asked how they responded to the change process, $63 \%$ indicated that they were anxious and worried about their impact (Table 4.5).

Table 4.5: Respond to the change process 


\section{Respond}

The process did not affect me, I continued with my routine behaviour.

I was optimistic that the process was essential to the stability and future of the business.

I was anxious and worried about the impact on me.

I was annoyed and angry about the process and am intolerant to change.
Frequency Percent

7

15

63

15
7.0

15.0

63.0

15.0

Participants were asked to rank how the change process affected them. Results showed that about half of the participants $(47 \%)$ were unsure whether they would lose their job. This was followed by the expectation of a higher workload even though their function was not affected $(23 \%)$. The ranking of all other statements are summarised in (Table 4.6).

\section{Table 4.6: Participants were affected by the change process}

\begin{tabular}{|l|c|c|c|c|c|}
\hline \multicolumn{1}{|c|}{ Statement } & \multicolumn{5}{c|}{ Ranking } \\
\hline & $\mathbf{1}$ & $\mathbf{2}$ & $\mathbf{3}$ & $\mathbf{4}$ & $\mathbf{5}$ \\
\hline I was unsure whether I would lose my job. & 47.0 & 9.0 & 1.0 & 17.0 & 26.0 \\
\hline $\begin{array}{l}\text { I would be expected to carry a higher workload even } \\
\text { though my function was not affected. }\end{array}$ & 23.0 & 26.0 & 11.0 & 37.0 & 1.0 \\
\hline $\begin{array}{l}\text { Guilty because I knew that my job was secure but my } \\
\text { fellow work colleagues were losing theirs. }\end{array}$ & 7.0 & 37.0 & 45.0 & 7.0 & 2.0 \\
\hline $\begin{array}{l}\text { Angry because I felt that the company should have } \\
\text { reviewed other options to remain competitive before } \\
\text { deciding to reduce the workforce. }\end{array}$ & 10.0 & 24.0 & 36.0 & 25.0 & 3.0 \\
\hline $\begin{array}{l}\text { I accept the process as change is needed for our } \\
\text { business to remain viable. }\end{array}$ & 9.0 & 3.0 & 2.0 & 16.0 & 67.0 \\
\hline
\end{tabular}

It was found that about two-thirds of the participants (63\%) highlighted that they did not receive any support, followed by $28 \%$ who indicated that assistance was given to them to handle issues within the new terms that were created (Table 4.7).

Table 4.7: Post the restructuring exercise has management offered any assistance

\section{Statement}

Individual sessions were offered by my manager/supervisor to assist me in coping with the changed environment.

Assistance to deal with my emotions was offered through the Human Resources Department.

Additionally, training was provided to successfully handle my new job profile.

\begin{tabular}{|c|c|}
\hline Frequency & Percentage \\
\hline 5 & 5 \\
\hline 12 & 12 \\
\hline 13 & 13 \\
\hline
\end{tabular}




\begin{tabular}{|l|c|c|}
\hline $\begin{array}{l}\text { My support was sought to determine how to make a positive } \\
\text { contribution to the new business goals. }\end{array}$ & 8 & 8 \\
\hline $\begin{array}{l}\text { Assistance was given to me to handle issues within the new } \\
\text { terms that were created. }\end{array}$ & 28 & 28 \\
\hline \begin{tabular}{l} 
No support was offered. \\
\hline
\end{tabular} & 63 & 63 \\
\hline
\end{tabular}

About half of the participants (48\%) reported that they rarely or never had an adequate worklife balance in this company. It was found that only one in six participants $(17 \%)$ reported that they had a clear indication of their role and prospects (Figure 4.6) and similar numbers also highlighted that they believed their skills were needed and would be harnessed in the future (Figure 4.7). When asked about short-term prospects in the organisation, more than two-thirds confirmed that there were short-term promotional prospects in this organisation (Figure 4.8).

The majority of the participants disagreed that the management initiative in bringing about the change process would sustain the business in the long term (74\%), 81\% did not believe that business had retained the right skill levels after the restructuring process, and $69 \%$ agreed that there were equal opportunities for both sexes in the technically skilled jobs in the company (Table 4.8).

\section{Table 4.8: Participants' opinions regarding change process and retaining right skills}

\begin{tabular}{|c|c|c|c|}
\hline Statement & Opinion & Frequency & Percent \\
\hline \multirow{2}{*}{$\begin{array}{l}\text { The management initiative in bringing about the change } \\
\text { process will sustain the business in the long term. }\end{array}$} & No & 74 & 74.0 \\
\hline & Yes & 26 & 26.0 \\
\hline \multirow{2}{*}{$\begin{array}{l}\text { The business has retained the right skill levels after the } \\
\text { restructuring process. }\end{array}$} & No & 81 & 81.0 \\
\hline & Yes & 19 & 19.0 \\
\hline \multirow{2}{*}{$\begin{array}{l}\text { There were equal opportunities for both sexes in } \\
\text { technically skilled jobs. }\end{array}$} & No & 31 & 31.0 \\
\hline & Yes & 69 & 69.0 \\
\hline
\end{tabular}

\section{DISCUSSION}

When the participants were asked of the relevance of change about half of them (47\%) were unsure whether they would lose their job followed by "they would be expected to carry a higher workload" even though their function was not affected (23\%). Lack of clarity on the aspect of increased workload suggests that poor communication is the contributor. This supports the theory by Cilliers (2012) who added that factors such as uncertainty and fear of increased responsibilities are part of the change process that creates this expectation.

Management support is another review that indicated a measurable imbalance with $72 \%$ reporting that there had been no management support during this change phase. Ochurub et al., (2012:42) add credence to the issue of management support. The recommendation for management intervention can be seen as ownership and accountability for worker interest in times of change. The key need by Company $X$ is the focus on skilled artisans due to the change from mass production to niche manufacture - this must be driven and owned by management and therefore is a recommendation accordingly.

Molaro (2014) indicated that during the process of change in the organisation, employees experienced fears of potential job loss sometimes through a restructuring process as revealed 
in this study where $63 \%$ of the respondents advised that they were actively seeking alternate employment.

This research indicated that $63 \%$ of the respondents reported feeling anxious and worried about their future in the company. This response fits in with the Prosci ADKAR model on resistance to change and unfortunately, the result places the scoring in the red zone of the model. This requires that managers take the initiative in reducing the anxiety levels by:-

- Educating and informing on progress in terms of the change process.

- What the future state entails for each employee?

- Communication must be concise and answer to when, how and why to mitigate the risk of rumours.

Paul and Barry (2013:446) indicate that when an organisation undergoes the process of change this has negative impacts on employees as they are not in control of the situation. This theory is, however, questioned in this study as $70 \%$ of the participants indicated that the change process positively affected their jobs. The possibility exists that having been through a reduction in headcount the remaining employees were saved from any further anxiety and this created a 'positive' atmosphere. The opportunity though, for further exploration or research in this regard, exists.

The result further indicates that coping post the transformation process is emotion-based rather than having problem-solving at its core. About two-thirds of the respondents indicated that they were seeking new employment opportunities due to feelings of insecurity. This must be seen by management as an opportunity to address the behavioural side where feelings of guilt, distrust and fear exist. Team building and the channelling of the corporate mission and vision would alleviate much of these concerns. Van Dyke and Coetzee (2012:89) stress that when employees are faced with job insecurities they tend to display detachment. The suggestion is for improved communication as this can assist in the healing process of post-traumatic experiences as well as restore some degree of trust.

Theron, et al., (2014) raised the concern of information-sharing and properly communicating the corporate vision as a part of an effective retention program. In terms of the assessment results at Company X, 70\% of the respondents indicated that there was no consultation prior to the change process, thereby leaving the employees in a precarious position of uncertainty. Management had to take the initiative in effectively communicating to all participants of the change process to encourage awareness, garner support, and instil ownership over the activities.

The further concern though is that of the $35 \%$ of employees that fell into the 11-15 years of service, the lack of understanding regarding the company's grading scheme, mentorship programs and training plans derived from performance appraisals, reflects an organisation that fails to communicate effectively with its employees. Theron et al., (2014) stresses that communication is one of the key elements of effective retention strategies.

More than two-thirds of the participants mentioned that there were only short-term promotional prospects in this organisation. This is a positive reflection on prospects which has to be driven by management. One of the drivers of retention is the issue of compensation which must be supplemented by transparency and consistency (Van Dyke \& Coetzee, 2012). The result of $63 \%$ choosing the option to seek new opportunities due to insecurity issues is a concern which management must address - benchmarked compensation needs to be established which will improve the level of confidence in the company as a valued employer (Theron et al., 2014). 
From a respondent perspective, $81 \%$ maintained that the right skills have not been retained post the restructure process. For a change in business strategy to be coherently successful answers to these questions should be understood and responded to positively. Omotoye (2011:11) supports the view that a loss of employees who have critical skills can impact negatively on service delivery. Therefore, it is imperative to identify and prioritise such skills. In terms of gender parity, it was found that the majority of the participants (72\%) were male. This is a concern, especially in the context of the affirmative action and employment legislation in South Africa. Beyond legislation, employment equity ratings as a unit of measure determine a company's marketability in the industry and for niche manufacturing. This will provide Company $\mathrm{X}$ with a platform for future business stability. Von der Ohe and Martins (2010:44) raise the issue of the glass ceiling which is the invisible barrier blocking women and minorities from management or skilled positions in organisations.

In the survey, it was found that the company is perceived as an employer that provides equal opportunities in technical jobs. However, with the gender imbalance, management has not capitalised on this opportunity. Management should be advised to ensure compliance with the Employment Equity Act No 55 of 1998 which emphasizes South African law in terms of having an equitable gender review at the workplace (Faught 2012).

The majority of the participants had no clear indication of their role and future prospects. Theron, et al., (2014:131), together with Faught (2012), emphasize the importance of growth opportunity using the Hay model (2002) - this aspect is a key contributor to employees deciding to 'stay or leave' an organisation. It is evident that even though performance appraisals were done with a 91\% acknowledgement, the bridge to the skills shortfall is not apparent. The management focus on the gap in the performance review to remedy or redress the shortcoming is unacceptable as this should have formed the basis of the training budget into the financial year.

A finding in this survey was that $74 \%$ reported that their career path was not mapped out or monitored. Van Rooyen, Du Toit, Botha and Rothman (2010) support the view that organisations need to take advantage of the different approaches to learning and development. It is either that companies develop their employees or they procure the required skills at a premium from the market. The domino impact is that salary/wage gaps become stretched within the percentiles which can be demotivating to the long-serving employees as the gap widens. Internal career growth and promotion foster challenges and as businesses have more information on internal candidates they fail to stimulate their growth (Grobler \& Warnich 2006). Prevalent at Company X is that $83 \%$ of the staff have over 10 years' experience with $20 \%$ of them having incomplete qualifications. This is an indicator that management has apportioned blame for their restricted growth.

The survey indicated the need for specific job functions at Company $\mathrm{X}$ in a list of priorities starting with artisan functions which dominated the top three disciplines. Faught (2012) explained at length that artisans did not prepare themselves for career progression by obtaining formal qualifications and found that employers did not make attempts either to encourage skill development and are quite satisfied if minimum requirements are met. This is reflected in the survey where the most critical skilled need is millwrights at $60 \%$ followed by toolmaker and then fitter/turner respectively. The further benefit that the survey has raised is that $20 \%$ of the surveyed employees have incomplete tertiary qualifications and this is the base to start from - considering the MERSETA (Manufacturing, Engineering and Related Services Education and Training Authority) funding benefit to the company. The opportunity to explore skill development also 
exists externally through Further Education and Training (FET) colleges and artisan training facilities which provide a substantial base to draw from.

Coetzee and Gunz (2012) maintain that there is a trend evident whereby older employees display greater organisational commitment and there is a defined relationship between age and business commitment supported by the fact that there are fewer job opportunities with increased age and specialisation. From the results perspective, $83 \%$ of the participants had more than 10 years of working experience. Established product and process knowledge are accepted within the employer/employee relationship after 10 years and with evidence of increased commitment, this supports a successful transformation in business strategy.

Van Dyke and Coetzee (2012) added that the concept of work-life balance, together with opportunities for career growth, using one's skills and knowledge in the company, compensation and challenging work are some of the most important retention factors for employees. Results reflect that $48 \%$ of the respondents indicated that they don't have a worklife balance at Company X. To understand the relevance of the literature which supports the sample testing it is vital that managers reduce the negative and promote the positive factors that impact work-life balance. Monitoring of working hours should be standard practice in a manufacturing facility, specifically as a result of overhead cost containment as well as legislative controls on maximum overtime allowed by the Basic Conditions of Employment Act 75 of 1997.

\section{RECOMMENDATIONS}

Based on the findings from the study, the following are recommended:

- The opportunity to review alternative motivational theories in the application of change management strategies for the automotive component industry.

- The influence of career-mapping and monitoring on employee commitment and retention within an enterprise.

- The effects that the change process has on the managers that are part of implementing the transformation within an organisation.

\section{CONCLUSION}

The findings on this study reflect that a change in business strategy did not consider all stakeholders and the resultant lack of communication created an environment of distrust conversely proportional to the intent of the initiative undertaken to strengthen the business growth and stability. The change relied specifically on the need for skilled staff for its success and has resulted in an environment that encourages staff turnover. It also highlighted the need for effective audits within the realm of human resources which drives the linkage between effective training needs review and fulfilment. The findings indicated that there are opportunities existent in securing the skills required for future business changes as well as encouraging responses that current staff are willing to improve the shortfalls for business stability in the long term.

\section{REFERENCES}

Bloom, N. \& Van Reenen, J. (2010). Why do management practices differ across firms and countries. Journal of Economic Perspectives Vol. 24, No1, 203-204. 
Burger, D.H., Crous, F. \& Roodt, G. (2013). Exploring a model for finding meaning in the changing world of work (Part 3: Meaning as framing context). SA Journal of Industrial Psychology/SA Tydskrif vir Bedryfsielkunde, 39(2), Art. \#1022.

Cilliers, F. (2012). Leadership coaching experiences of clients with Alexithymia. SA Journal of Industrial Psychology/SA Tydskrif vir Bedryfsielkunde, 38(2), Art. \#995.

Coetzee, M. \& Gunz, H. (2012). Careers and retention of staff in the $21^{\text {st }}$ century in the world of work: Introduction to the special edition. SA Journal of Human Resource Management/SA Tydskrif vir Menslikehulpbronbestuur, 10 (2), Art. \#505.

Coetzee, M., Mitonga M.J. \& Swart, B. (2014). Human resource practices as predictors of engineering staff's organisational commitment. SA Journal of Human Resource Management/SA Tydskrif vir Menslikehulpbronbestuur, 12 (1), Art. \#604.

Dhliwayo, S. (2014). Entrepreneurship and competitive strategy: An integrated approach. The Journal of Entrepreneurship, 23(1):115:135.

Du Toit, A.S.A. \& Sewdass, N. (2014). A comparison of competitive intelligence activities in developing countries, Acta Commercii 14(1), Art. \#234.

Faught, C. (2012). Total rewards: A study of artisan attraction and retention within a South African context - partial fulfilment in Masters of Commerce in Organisational Psychology, University of Cape Town.

Joāo, T.F. (2010). The relationship between perceived career mobility, career mobility preference, job satisfaction and organisational commitment. [pp 61-73], unpublished master's dissertation. University of South Africa, Pretoria, South Africa.

Kaliannan, M. \& Adjovu, S.N. (2015). Winning the talent war via effective employee engagement: a case study. Journal of Business and Financial Affairs 3:132.

Khoele, A. \& Daya, P. (2014). Investigating the turnover of middle and senior managers in the pharmaceutical industry in South Africa. SA Journal of Human Resource Management/SA Tydskrif vir Menslikehulpbronbestuur, 12(1), Art. \#562.

Meyer, M., Roodt, G. \& Robbins, M. (2011). Human sources risk management: Governing people's risks for improved performance. SA Journal of Human Resource Management/SA Tydskrif vir Menslikehulpbronbestuur, 9(1), Art. \#366.

Molaro, A. (2014). Merging large and complex library organizations. (Advances in Library Administration and Organization, 32:265-306.

Mosavi, S.A. \& Gaedhi, M. (2012). An examination of the effects of perceived value and attitude of customer's behavioural intentions in e-shopping. African Journal of Business Management, 6(5): 45.

Nujjoo, A. \& Meyer, I. (2012). The relative importance of different types of rewards for employee motivation and commitment in South Africa. SA Journal of Human Resource Management/SA Tydskrif vir Menslikehulpbronbestuur, 10(2), Art. \#442.

Ochurub, M., Bussin, M. \& Goosen, X. (2012). Organisational readiness for introducing a performance management system. SA Journal of Human Resource Management/SA Tydskrif vir Menslikehulpbronbestuur, 10(1), Art. \#389.

Omotoye, A.M. (2011). An evaluation of retention and career management policies for senior management in the SA public service in Limpopo. An unpublished dissertation submitted to the University of Pretoria. 
Paul, G.W. \& Berry, D.M. (2013). The importance of executive leadership in creating a postmerged organisational culture conducive to effective performance management. $S A$ Journal of Human Resource Management/SA Tydskrif vir Menslikehulpbronbestuur, 11(1), Art. \#446.

Schreuder, D. \& Coetzee, M. (2010). An overview of industrial and organisational psychology research in South Africa: A preliminary study. SA Journal of Industrial Psychology/SA Tydskrif vir Bedryfsielkunde, 36(1), Art. \#903.

Sekaran, U. \& Bougie, R (2009). Research methods for business: A skill building approach. $5^{\text {th }} E d$. Chichester: John Wiley \& Sons Ltd.

Shumba, A. \& Naong, M.N. (2012). Factors influencing students' career choice and aspirations in South Africa. Journal of Social Sciences. DOI: 10.1080/09718923.2012.11893096.

Swanepoel, S., Botha, P.A. \& Mangonyane, N.B. (2014). Politicisation of performance appraisals. SA Journal of Human Resource Management/SA Tydskrif vir Menslikehulpbronbestuur, 12(1) Art. \#525.

Terblanche, N. (2014). Some theoretical perspectives of co-creation and co-production of value by customers. Acta Commercii, North America, 7(1).

Terera, M. \& Ngirande, N. (2014). The impact of rewards on job satisfaction and employee retention. Journal of Social Science. 5(1). DOI: 10.5901/mjss.2014.v5n1p481.

Theron M., Barkhuizen, N. \& Du Plessis, Y. (2014). Managing the academic talent void: Investigating factors in academic turnover and retention in South Africa. SA Journal of Industrial Pyschology/ SA Tydskrif vir Bedryfsielkunde; 40(1). DOI: https://doi.org/10.4102/sajip.v40i1.1117.

Uys, J.W., Schutte, C.S.L. \& Esterhuizen, D. (2011). Trends in a South African Industrial Engineering Research Journal: A textual information analysis perspective. The South African Journal of Industrial Engineering, 21(1): ISSN 2224-7890. DOI: 10.7166/21-162.

Van Dyk, J. \& Coetzee, M. (2012). Retention factors in relation to organisational commitment in medical and information technology services. SA Journal of Human Resource Management/SA Tydskrif vir Menslikehulpbronbestuur, 10(2), Art. \#433.

Van Rooyen, L., Du Toit, D.H., Botha, E. \& Rothmann, S. (2010). Artisan retention in an organisation in South Africa. SA Journal of Human Resource Management/ SA Tydskrif vir Menslikehulpbronbestuur, 8(1), Art. \#300.

Von der Ohe, H., \& Martins, N. (2010). Exploring trust relationships during times of change. SA Journal of Human Resource Management/SA Tydskrif vir Menslikehulpbronbestuur, 8(1), Art. \#256.

Weisul, K. (2011). Why smart people make lousy teams, Occupational Outlook Handbook [Online]. Available: http://www.bls.gov/oco/ocos053.htm; [Accessed: 30 January 2012].

Williams, F. (2013). The quality maturity model: Assessing organisational quality culture in academic libraries. Thesis submission to Brunel University. 